\title{
The Regional Airports' Problems in the Slovak Republic: The Case Study of Žilina Airport
}

\author{
Alena Novák Sedláčková ${ }^{1, *}$, and Denisa Švecová ${ }^{1}$ \\ ${ }^{1}$ Air Transport Department, University of Žilina, Univerzitná 1, 01026 Žilina, Slovakia
}

\begin{abstract}
This paper solves the regional airports in the Slovak Republic and the problems they have been facing while focusing on the specific, i.e. 'small regional' airports category (up to 200,000 passengers transported per year). Moreover, the issue of Slovak regional airports' problems is connected mainly to their funding system, which has shown to be insufficient, and the extent of their utilization in relation to their untapped potential. It was proven that small regional airports with an annual throughput under 200,000 passengers are unable to break even and to cover their operational costs as well and thus must be subsidized. Funding of 'small' regional airports can be considered as not only the Slovakian problem, actually it is a broad long-term EU problem and there were several approaches established by the EU related to adjustment of those issues. The current legislation is represented by new Commission Regulation (EU) 2017/1084 thanks to which the state aid at the EU level has been greatly simplified. The paper focuses on the case study of chosen Slovakian small regional airport near Žilina, in Dolný Hričov, which the possibilities of several measures for its revitalization and efficiency improvement are depended on the operational-technical characteristics and position within the region.
\end{abstract}

\section{Introduction to Slovak regional airports' problems - (in)sufficient funding and (un)utilized potential?}

In the Slovak republic, there are currently more than thirty airports - thirteen public and six with the status of an international public airport with the permission to provide international commercial operations, handling, rescue and firefighting, and air traffic services in Slovakia: Bratislava, Košice, Žilina, Piešt'any, Sliač and Poprad-Tatry. All of them have a legal form of a joint-stock company and four of them are considered to be the small regional airports: Žilina, Sliač, Poprad-Tatry and Piešt'any [1]. The issue of Slovak regional airports' problems is mainly connected to their funding system and the extent of their utilization as well. Every particular regional airport in Slovakia is unique, has its own status within the region which serves; furthermore, every airport is specific and can be found in certain situation while facing several long or short-term problems [2]. Within the Slovak regional airports, the small airports with an annual throughput under 200000 passengers represent the special category that is considered not to be able to cover its operational costs

"alena.sedlackova@fpedas.uniza.sk 
and therefore, must be subsidized [1]. Funding of the airports' modernization or infrastructure construction from the public resources, taking into consideration the state budget, limitedness to the European legislation in relation to state subsidization, are considered to be the biggest problems of every Slovak regional airport. Although the argumentation of Slovak Ministry of Transport and Construction about the state support of air transport impracticability is still ongoing, there are several appropriate schemes of airlines and small airports' support, based on the EU regulatory framework (Commission Regulation (EU) 2017/1084 of June 2017) and thus such approach cannot be accepted.

\section{The EU regulatory framework of regional airports}

In order to understand these problems, it is necessary to define the key term, i.e. 'regional' airport as 'an airport with average annual passenger traffic of up to 3 million passengers' according to Article 1 paragraph 153 of the Commission Regulation (EU) 2017/1084 of June 2017 amending Regulation (EU) No 651/2014 as regards aid for port and airport infrastructure [3]. The guidelines on state aid were established as a part of several changes leading to common air transport services' market and in history, there were three phases of their development: the 1 -st phase $(1984$ - 2005) - no particular guidelines were in existence, the 2-nd phase $(2005$ - 2014) - Communication from the Commission: Community guidelines on financing of airports and start-up aid to airlines departing from regional airports (2005/C 312/01) were in existence and the 3-rd phase (since 2014) Communication from the Commission: Guidelines on state aid to airports and airlines (2014/C 99/03) have been in existence.

\subsection{The overview of current European regulatory framework: Commission Regulation (EU) 2017/1084}

As far as the small airports are concerned, state aid at the EU level has been greatly simplified since 14 June 2017. It is interesting that the threshold with simplified rules for the very small airports was set up to 200,000 passengers per annum. In line with the Guidelines on State Aid to Airports and Airlines (2014/C 99/03) it was possible to subsidize airports even before that date. However, this regulation, which also comprised very small airports, was administratively demanding and also had a number of limitations.

According to Regulation, investment aid to regional airports 'should therefore be covered by the block exemption in Regulation (EU) No 651/2014, provided that those conditions are fulfilled. It would not be appropriate to establish a notification threshold in terms of the amount of aid, since the competitive impact of an aid measure depends mainly on the size of the airport and not on the amount of aid'. As far as the conditions for the exemption of investment aid from the notification requirement are concerned, they should aim at limiting distortions of competition that would undermine a level playing field in the internal market, by ensuring the proportionality of the aid amount. The EC Regulation includes two conditions with respect to investment aid: The aid intensity should not exceed a maximum permissible aid intensity, which varies according to the size of the airport and the aid amount should not exceed the difference between the eligible costs and the operating profit of the investment [1-3]. 


\section{Methodology}

This paper is dedicated to the actual state of regional and small regional airports' problems in the Slovak Republic in relation to their funding system and the extent of their utilization, while focusing on the case of Žilina Airport. Firstly, with the respect to [4-8] research studies and papers the operational-technical characteristics and economic indicators of Žilina airport were examined and then we focused on the airport's actual economic situation by analysing its business environment and its position within the region and with the use of partial indicators of the economic benchmarking, chosen financial and operational-performance indicators were calculated. The conclusions incorporate several proposals for improving the efficiency at the airport and recommendations for its further development.

\section{4 Žilina Airport and its economic situation analysis}

This part of paper is dedicated to the basic information, operational-technical characteristics of Žilina airport, the airport's position within the region and its business environment analysis with regard to other domestic competitive airports ' position, as well as the socialeconomic impacts on the adjacent region. To understand the actual economic situation, we focused on the economic and operational indicators of the airport for the period of years 2013-2016 based on the numbers and figures as stated in the Annual Report of Žilina airport.

Žilina airport is an international public airport located near the village Dolný Hričov approximately $15 \mathrm{~km}$ from Žilina city centre and $12 \mathrm{~km}$ from the Žilina railway station. It is used for international and domestic flights, as well as for private flights, amateur sport and other special flights. It serves as primary training airport for the pilot students of the University of Žilina. The airport's operator is company Letisková spoločnost' Žilina a.s. owned by Ministry of Transport and Construction of the Slovak Republic (99.53\%) and Žilina Self-governing Region $(0.46 \%)$. The fundamental part of the Airport is represented by: the take-off and landing RWY 06/24 - 1,150 m long and $30 \mathrm{~m}$ wide and is equipped with ILS (Instrument Landing System) that allows operating in low visibility conditions, Glide Path and Localiser for performing the precision approaches [9-10].

\subsection{The position of Žilina Airport within the region and its business environment analysis}

Žilina airport has a strategic position, as is situated at the crossroad of very important European corridors: railway, traffic and in the future water-borne transportation, as well. The airport's area is directly connected to D1 motorway thanks to which the south and north of Slovak Republic can be connected. At the same time, the main railway line Bratislava - Žilina leads through this locality with the possible access to the Dolný Hričov railway station. Such mutual connection: airport - motorway - railway forms an ideal place for establishment on an industrial zone with various activities in the industry, transportation or tourism sphere. The Airport's importance resides in the access facilitating for international clients and investors cooperating with companies within the region. Moreover, its location is suitable for such kind of businesses directly associated with aviation, since every 'bigger' investment (i.e. INA Kysuce, Volkswagen Martin, SCP Ružomberok, etc.) in the region would never exist without aviation. The active tourism within the region has a huge potential for the air transportation development taking into consideration several spa cities (Rajecké Teplice, Bešeňová), hiking (Martinské Hole, Vrátna valley) or exhibitions. 
By establishing the regular flight connections, it would enable providing of flights among Žilina and other holiday Mediterranean resorts.

The foreign investor's interest in business activities within the northwest Slovakian region is clearly obvious as the amount of direct foreign investment is on the third position in Slovakia, following Bratislava and Košice. Statistically, the increasing tendency in business activities and foreign business interests can be expected in the following years within the region. The economic effect of a regional airport can start when being actively connected with the local economy and can bring considerable benefits reflected in the economic development of catchment area [9].

\subsubsection{Domestic competitors}

According to Reiff (2007), the competitiveness of adjacent airports has to be assessed at least from two sides: from the point of view of the airport's technical parameters on the one hand and from the point of view of a network of an airliners/variety of flights offered by airliners. It is also obvious that Žilina airport, is not a direct competitor of Bratislava airport, mainly due to the absence of regular air connections and constraints coming out from the runway characteristics. The airports Bratislava and Žilina can compete witch each other only in the segment of non-regular air transport of passengers on the regional lines (up to 100 passengers), of general aviation, training flights and cargo flights up to approximately 70 tons, as this segment is the most perspective from the point of view of possibilities of the market processing, location of Žilina airport in relation to Bratislava, with respect to other Slovak districts [11]. From abroad are potential competitors Airport Ostrava in Czechia and Katowice Airport in Poland.

\subsection{Economic situation analysis and recommendations for improving efficiency}

Alike the other Slovak regional airports, also at the Airport of Žilina, the impacts of economic depression as well as the international conflicts appeared in the last five years with the direct effect on the airport's performance. On the basis of data obtained from FinStat and Annual reports of Žilina airport, we focused on the assessment of several areas of Žilina airport's efficiency by calculating chosen partial indicators of the economic benchmarking, to provide the complex picture of the actual economic situation at Žilina airport.

Table 1. Financial indicators of Žilina airport between years 2013 - 2017. Source: [9]

\begin{tabular}{|c|c|c|c|}
\hline Year & Profit/Loss & $\begin{array}{c}\text { Total Revenues } \\
\text { (EUR) }\end{array}$ & Total Costs (EUR) \\
\hline $\mathbf{2 0 1 3}$ & $+109,304$ & $1,007,286$ & 967,982 \\
\hline $\mathbf{2 0 1 4}$ & $-475,773$ & 479,908 & 955,681 \\
\hline $\mathbf{2 0 1 5}$ & $-149,791$ & 918,099 & $1,067,890$ \\
\hline $\mathbf{2 0 1 6}$ & $-137,191$ & 707,440 & 844,631 \\
\hline $\mathbf{2 0 1 7}$ & N/A & 818,526 & 856,287 \\
\hline Year & $\begin{array}{c}\text { Material, electricity } \\
\text { costs (EUR) }\end{array}$ & $\begin{array}{c}\text { Personal costs } \\
\text { (EUR) }\end{array}$ & $\begin{array}{c}\text { Other operating } \\
\text { costs (EUR) }\end{array}$ \\
\hline $\mathbf{2 0 1 5}$ & 94,358 & 43,837 & 59,174 \\
\hline $\mathbf{2 0 1 6}$ & 335,749 & 307,359 & 307,356 \\
\hline $\mathbf{2 0 1 7}$ & 16,165 & 36,488 & 26,622 \\
\hline
\end{tabular}


According to Table 1, it is obvious, that Žilina Airport is in unfavourable financial situation, since the company was loss-making in the period of years 2014 - 2016, furthermore, in 2015 the total costs exceeded more than 1 million EUR. The airport is not able to exist without any external support and must therefore be subsidized. In 2017, the company was provided with state funds to the airport's security and firefighting services, in the total amount of 266,659 EUR.

Table 2 indicates that the airport's operational performances correspond to its 'short' RWY utilization. Total number of movements is greatly influenced by the training flights' number of the University of Žilina. It is also obvious that since 2015, the number of passengers carried has been on decline, as a result of scheduled flights cancellation on the part of CSA as well as low demand for the air transport services in general. On the other hand, the scheduled flights cancellation led into the slight increment in the business flights category (aerotaxi), as a result of shift in number of passengers carried on scheduled business flights to passengers carried by aerotaxi. In 2016, the airport's operational performances related to aircraft landings (in tonnes) had rising tendency when compared to previous years and this trend also continued in 2017, when exceeded 8,200 tonnes. The situation as for the number of passengers transported, the amount of cargo carried and tonnes of landings was totally different in the period of years 2011-2012, as the airport was operating the regular flight connection between Žilina and Prague, which was finally cancelled in July, 2012.

Table 2. Operational-performance indicators of Žilina airport between years 2011 - 2017. Source: [9]

\begin{tabular}{|c|c|c|c|c|}
\hline Year & $\begin{array}{c}\text { Number of } \\
\text { movements (-) }\end{array}$ & $\begin{array}{c}\text { Number of } \\
\text { passengers } \\
\text { carried } \\
(-)\end{array}$ & $\begin{array}{c}\text { Amount of } \\
\text { cargo carried } \\
\text { (kg) }\end{array}$ & $\begin{array}{c}\text { Aircraft landings } \\
\text { (tonnes) }\end{array}$ \\
\hline $\mathbf{2 0 1 3}$ & 7,649 & 408 & 325 & 6,858 \\
\hline $\mathbf{2 0 1 4}$ & 6,311 & 245 & 2,852 & 5,225 \\
\hline $\mathbf{2 0 1 5}$ & 7,832 & 888 & 1,252 & 6,627 \\
\hline $\mathbf{2 0 1 6}$ & 7,451 & 298 & 1,200 & 6,781 \\
\hline $\mathbf{2 0 1 7}$ & 8,911 & 421 & 526 & 8,227 \\
\hline
\end{tabular}

\subsubsection{Cost effectiveness indicators calculation for Žilina Airport}

The efficacy of Žilina airport's costs usage in EUR, was expressed by the calculation of total operating costs proportion to amount of cargo carried (part of the Table 1 and Table 2). The Costs per 1 tonne of cargo carried in 2015 were 852,947.284 EUR, in 2016 703,859.167 EUR and in 2017, the costs reached the amount of 1,627,922.053 EUR. The total costs amount was on the decrease between the years 2015 - 2017 and also the amount of cargo carried had a declining tendency, which was reflected to costs per one tonne of cargo carried: in 2014 the costs reached almost 853,000 EUR and in the following year, it decreased to merely 703,900 EUR. On the other hand, in 2017, the situation at the airport changed and the amount of cargo carried decreased, by almost 0.8 tonnes when compared to year 2015 and furthermore, it was reflected on the dramatic increase in the costs which were expended on every particular tonne of cargo carried. Moreover, the amount of cargo as well as number of passengers carried fell sharply; this situation could potentially be caused by unfavourable economic conditions at Žilina airport. 


\subsubsection{Cost structure indicators calculation for Žilina Airport}

Table 3 indicates that the amount of personal costs was on the decrease between the years 2015 - 2017 that signifies that the airport was expending less financial means on its employees, which had an impact on the decreasing amount of total costs. On the other hand, compared to the period of $2015-2016$, the total costs had increasing tendency in 2017, as in 2016 the amount of total costs equalled 844,631 EUR and, in the following year, increased by more than 11,600 EUR. This had an impact on the personal costs proportion to total costs: in 2015, the ratio of personal costs accounted for 31.440 percent while in the following year, the ratio increased by 4.950 percent and in 2017 it decreased slightly, to 25.894 percent.

In the next calculation, as a cost item, material and electricity consumption costs were chosen and the proportion of material costs to total costs was calculated and expressed in percent. The amount of material and electricity consumption costs was on the increase between the years 2015 - 2016 that signifies that the airport was expending more funds on its material facilities, and the electricity consumption as well, which had an impact on the amount of total costs; on the other hand, compared to the period of 2016 - 2017, the material costs had declining tendency, as in 2016 the amount of material costs equalled more than 335,000 EUR and, in the following year, decreased dramatically to almost 16,200 EUR. This had an impact on the material costs proportion to total costs: in 2015, the ratio of material costs accounted for 8.836 percent while in the following year, the ratio increased by almost 30.920 percent and in 2017 it decreased to almost 2 percent.

Table 3. Cost structure indicators for the years 2015, 2016 and 2017. Source: [9]

\begin{tabular}{|c|c|c|c|c|}
\hline Year & $\begin{array}{c}\text { Personal costs } \\
\text { (EUR) }\end{array}$ & $\begin{array}{c}\text { Material costs } \\
\text { (EUR) }\end{array}$ & $\begin{array}{c}\text { Personal costs } \\
\text { proportion to total } \\
\text { operating costs } \\
\text { (EUR) }\end{array}$ & $\begin{array}{c}\text { Material costs } \\
\text { proportion to total } \\
\text { operating costs } \\
\text { (EUR) }\end{array}$ \\
\hline $\mathbf{2 0 1 5}$ & 335,749 & 94,358 & 31.440 & 8.836 \\
\hline $\mathbf{2 0 1 6}$ & 307,359 & 335,749 & 36.390 & 39.751 \\
\hline $\mathbf{2 0 1 7}$ & 307,356 & 16,165 & 35.894 & 1.888 \\
\hline
\end{tabular}

\subsubsection{Revenue structure indicators calculation for Žilina Airport}

According to Table 4, the revenue structure at Žilina airport in percent was expressed by the calculation of sales and services revenues proportion to total revenues. The amount of revenues from sales and the airport's services was on the increase between the years 2015 2017 that signifies that the airport was generating profit from its sales and services activities, which had an impact on the increasing amount of total revenues - as in 2016 the amount of total revenues equalled 707,440 EUR and, in the following year, increased by more than 88,900 EUR. Regardless of the declining total revenues tendency between $2015-2016$, the proportion of sales and services revenues to total revenues was on the increase: as in 2015 the ratio was 14.159 percent and in 2017 , it rose by nearly 13.710 percent. 
Table 4. Revenue structure indicators for the years 2015, 2016 and 2017. Source: [9]

\begin{tabular}{|c|c|c|c|}
\hline Year & $\begin{array}{c}\text { Sales and services } \\
\text { revenues (EUR) }\end{array}$ & $\begin{array}{c}\text { Total revenues } \\
\text { (EUR) }\end{array}$ & $\begin{array}{c}\text { Sales and services } \\
\text { revenues proportion to } \\
\text { total revenues (\%) }\end{array}$ \\
\hline $\mathbf{2 0 1 5}$ & 129,992 & 918,099 & 14.159 \\
\hline $\mathbf{2 0 1 6}$ & 161,957 & 707,440 & 22.893 \\
\hline $\mathbf{2 0 1 7}$ & 228,107 & 818,526 & 27.868 \\
\hline
\end{tabular}

\subsection{Conclusions and recommendations for the airport's revitalization}

As was written at the beginning of section 4, Žilina airport has a strategic position, as is situated at the crossroad of very important European corridors. Such mutual connection: airport - motorway - railway forms an ideal place for establishment an industrial zone with various activities in the industry, transportation or tourism sphere. The Airport's importance resides mainly in the access facilitation for international clients and investors cooperating with companies within the region [11]. As it was proven, the Airport has been facing an unpleasant financial and economic situation for over a past few years; furthermore, there is a lack of 'traffic' in relation to minimum revenues generated by airport charges. Additionally, there are several international public airports in the close vicinity of Žilina, i.e. Bratislava, Ostrava or Katowice, located within $200 \mathrm{~km}$ from the Airport that are in very good economic condition and are thus used by passengers in order to satisfy their demand for air transport services. The Airport's operating company was loss-making in the period of years 2014 - 2016, and in 2015 the total costs exceeded more than 1 million EUR and subsequently, the Airport is not able to exist without any external support and must therefore be subsidized. In 2017, the company was provided with state funds to the Airport's security and firefighting services, in the total amount of 266,659 EUR.

In order to make the Airport surplus-making again, it should concentrate on scheduled and non-scheduled air transport development as well as to start the dialogue with the airliners or travel agencies which could potentially be interested in starting their business at Žilina Airport and could revive scheduled charter flight connection between Žilina and Prague, operated in the past. Or to analyse the possibilities of opening the regular flight routes into various European destinations operated by low-cost airlines, provided that the Airport's operating company would accept several investments to the modernization of the Airport's infrastructure and its RWY's extension to at least 2,100 meters length which is minimum runway requirement for the most common aircraft types used by low-cost airlines: Boeing 737-800 and Airbus 320 [1, 11]. Moreover, the Airport should concentrate on active and passive tourism in the region and on finding an appropriate investor or strategic partner who could potentially be willing to put money into the aforesaid infrastructural investment.

For providing the proposal of measures for the Airport's revitalization, we addressed several specialists from the Ministry of Transport, the academic environment and Žilina Airport, as well. They all agreed on keeping the Airport's existence, as it still has its importance for the further growth and development of the north-western Slovakian region. The specialists also pointed out the fact that since 2005, there has not been created any efficacious model for the further regional airports' sustainment from the part of Slovak Ministry of Transport and also creation of strategic program for regional airports by The Ministry of Transport including an acceptance of conditions for the Public Service Obligations development is no less important [2]. 
This paper was written as one of the scientific outputs of the project No. 1/0624/18 -Business models of regional airports in the context of state's and the European Union's transport policies.

\section{References}

1. A. Kazda, M. Hromádka, B. Mrekaj, TRPRO-INAIR, 59 (2017)

2. A. Novák Sedláčková, D. Švecová, TRPRO- INAIR (to be published)

3. Commission Regulation (EU) 2017/1084 of June amending Regulation (EU) No $651 / 2014$ as regards aid for port and infrastructure, notification and thresholds... par.153, (2017)

4. A. Tomová, A. Martišová, Business and management '2014, 2, pp. 597-603 (2014)

5. K. Havel, v. Balint, A. Novak,A., Communications - Scientific Letters of the University of Zilina, 19, 2, pp. 145-147 (2017)

6. N. Zacik, A. Novak, Proceedings of the Third International Conference on Traffic and Transport Engineering (Ictte), pp. 31-35 (2016)

7. M. Turiak, A. Novak Sedlackova, A. Novak, Telematics - Support for Transport, 471, pp. 29-37 (2014)

8. P. Kurdel, M. Ceskovic, L. Nyulaszi, F. Adamcik, Nase More, 62, 3, pp. 233-236 (2015)

9. Annual report of Žilina airport. The Airport's Financing Plan, 35 (2017)

10. Aeronautical Information Service SR, AIP LZZI AS 2.1. LZZI - Žilina (2018)

11. Ministry of Transport of the Slovak Republic, Žilina airport company analysis 2018 